E 396

.E95

Copy 1

\title{
DIARY OF THOMAS EWING, AUGUST AND SEPTEMBER, I84.
}

REPRINTED FROM THE

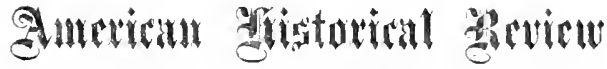


E396

. E 45 


\section{I)(UMIENTS}

\section{Diary of Thomas Eating. August and September, 1811}

SrTer the dramatic breach between l'resiblent fiver and his Cabinet in September, Isfl, its members justified themselves hy public letters. That of Thomas Ewing, secretary of the treasury. first printed in the National Intelligencer, is now most easily found in Viles Register. ISI. 3.3-34. It appears that it did not rest on memory alone, but that Secretary Ewing, as soon as he scenterl danger to the relations between I'resident 'Tyer and the executive alvisers inherited from Iarrison, in the course which the l'resilent was pursuing in regard to the bank act, began to keep a liary of the transactions relative to that and other measures. The manuscript of this diary now belongs to his grandson. Mr. Thomas Ewing of New lork City, but a copy of it is possessed by the library of Ohio Lniversity at Marietta. To Mr. ENing and to Mr. C. L. Martzolff of that university we are indelsted for the opportunity to print this valuable record. which, as will be seen, contains much information that is not to be fomd in the letter in Niles.

Not all parts of the manuscript printed below are of the same date. The first three paragraphs were prefixed to the diary proper. The grandson of Secretary Ewing states however that, judging from the handwriting, they are of about the same date. The next three paragraphs are in his handwriting of much later date. The essential portion, beginning with the words "On the morning of the 16th August", are plainly contemporary. The last paragraph under September I is shown by the handwriting to be a later insertion. Such is also the character of the final three paragraphs.

A full discussion of the whole crisis from the point of view of the President may be found in Dr. Lyon (i. Tyler's Letters and Times of the Tylers. II. 39-123.

Thomas Ewing ( $1789-187 \mathrm{I})$ was graduated from the ohio Unirersity in ISI5, practised law for several years at Lancaster. Ohio. Was a Whig senator from that state $1831-1837$. secretary of the treasury March 5-September 13. I\&.4, sccretary of the interior I $849-1850$, senator again $1850-1851$, and in 1861 a lelegate to the reace Conference, of which Ex-President Tyler was presilent.

AM. HIST. REV., VOL. XYHI.-7. 
Is and at the alection of Genl. Harrison to the Presideney was informally known to him, he acklessed me a letter moting me to take a place in his calbuet and signifying that the situation of 1'. M. G. Was the one he progued to offer me.

I bad leen long aware that public opinion had designated me for this, of some other place in the Cabinet, and thougle Genl. Ilarrison had never in the most rente manner linted at sueh a thing I hatel no doubt that it was his purpose to matke me the offer. My mind being mate up on the subject I accepted. with all due acknowledgments for the honor propused to be conferred and the framk and generous promptness with which it hat heen offered nue. I commmicated this for the present to no one hut my wife and my eldest son in whose secrecy 1 had full confielence, as 1 deemed it ly no means proper that the fact shombl first transpire through me. In the same letter Cienl. Ilarrison named Mr. IVebser as his proposed Secretary of State anel public opinion had defintively settled on $1 \mathrm{r}$. Crittenden as Attorney General, Mr. Bell harl heen much spoken of for the War Department and several other sentlemen were named for other Departments but no one ristinctly pointed to by acheral public opinion.

The lecgislature of ()hio met in Columbus on the first Monday in Decenber. The Court in liank sat at lhe same time and the Circuit Court shortly aiter. I was engaged as comnel in many important cases in these cotirts and necessarily spent several weeks in that city about their trial. llaving disposed of them and arranged nuy private business as well as I was able in so short a time, I set out for lV ashington and arrivel in the city early in Feluruary. By this time it was pretly well mulerstoml that I was to be a member of the Cabinet. but it was by 110 means so well settled what particular post I was to fill. The imfreison beame strong and was comstantly gathering strength that I should he placed at the head of the Treasury. liut in the midst of this meertainty I was rerwhelned with applications for office in both Defartments especially in the Genl. Post Office which had by far the largest share of fatronage. For so completely hal it become a settled political axiom within the last twelve years, "to the victors belong the spoils", that all men of hoth parties secuned to suppose that lhere would be an immediate and miveral sweep of all the officers then in place. There was alon another reason and a more just one for this opinion of the puldic and I miay saly mendate of the popmlar will. It had heen the fwlicy of the party juit thrust from power. to retatin in office none but their atiag politiral allherents, those who would go for them thorough in all thinge; amb the performatuce of official duty. was far less requisite to it tombe of uftice than electioneering services. Hence the offices had lecome for the muet part filled witl luawling offensive political partisans, wi a bery low moral stambarl- their official duties performed les sub-

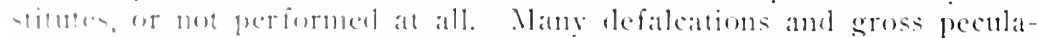

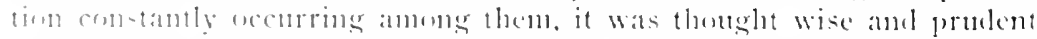

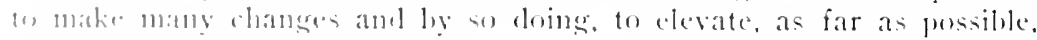
the official utamelatel and ensture a more fathlul execution of official thitice.

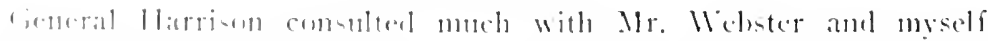

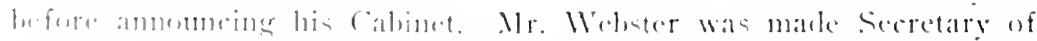

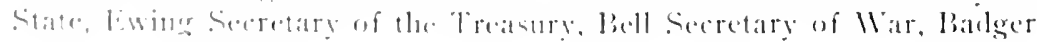


of the Navy, Frank Granger leust Master fieneral and John J. Crittenden Attorney fieneral. There was perfect harmony and goud feeling of the members of the Cabinet, with each other, and hetween them and the leading members of the Whig party generally-but the quict of the Administration and of the conntry was greatly disturbed by the sudden death of General Iarrison.

Immediately on his demise Mr. Webster dispatcherl a special messenger to Jom 'Tyler the Vice l'resident with the intelligence who in a few days cane to Washington and was inategurated as l'resident. The Cabinet convened to receive him, and he very promptly and eourtents requested $u s$ all to continue in our then present position as his conncil.

An extra session of Congress had been called which met in May. One of their furst acts, under the leat of Mr. Clay, was to pass an alet to recharter the Bank of the United States, and restore to it the public deposits and fiscal agency, and therein was for the first time disclosed a serious difference between the I'resident and the party who hat elected him, including nearly all the nembers of his Cabinet. The liank bill was passed early in August, and the President against the arlyice of his Cabinet determined to veto it. I saw clearly that the Ammistration was approaching a catastrophe, and on the I $\sigma^{\prime \prime}$ commenced and kept a diary for the month precerling its dissolution. I give it in full as it was then written.

On the norning of the I6" Angust I called to see the President and found him putting together the V'eto Nessage on the Bank Bill, in order to send it to the Senate. We had some conversation on the subject, and he read to me certain parts of the message, especially that which contained his strictures on the $16^{\prime \prime}$ fundamental article. While thus engaged Mr. Bell, Secretary of War, cante in and joined us in the conversation. It was observed by Mr. Bell, that although the Veto would create a great sensation in Congress yet he thonght the minds of our friends much better prepared for it than they were some days ago, and he hoped it would be calmly received, especially as it did not shut out the hope of some Bank. The President replied yes, he thought so-his mind had been made up from the first, and he had delayed his message until now that theirs might become quieted-that really they ought to make no difficulty about it, he had sufficiently indicated in his message what kind of Pank he would approve and they might if they saw fit, pass such a one (which would be more acceptable to the country than this) in three days.

The next day ( $\left.y^{\prime \prime}\right)$ I called and found the President in conversation with Mr. Sergeant of the House and Mr. Berrien of the Senate. I was about to retire but he invited me to sit, observing that the conversation was one to which I should he a party. Those gentlemen had come informally from the Whigs of the two Hiouses to confer with the President on the subject of a Bank or Fiscal Agent such as might be acceptable to him, and meet the wishes and wants of the Treasury and the country-much was said upon the subject. Mr. Sergeant stated his understanding of that part of the message which recommends agencies, with power to deal in Exchange etc. and wished to have a clear avowal from the President on that subject. The Presiclent in reply sail that he considered the message sufficiently explicit on that point. That he

\footnotetext{
${ }^{1}$ John Sergeant of Pennsylvania and Senator John M. Berrien of Georgia.
} 
divl not think it hecame him th draw out a plan of a bank, but he thought it easy to asecratin from the general conrse of his argmuent what he would approwe. In the comrse of the conversation I obscrved that I understous the I'resitent to have no objection to a Bank located in the District of columbia, employing agents in the several States, to perform the services repuited of it by the Government as a fiseal agent, and inciulemal to those duties to deal in exchange, and wo all other acts which the lituk proposed in the bill which he hat rejected might to except the making of local discounts. To this the President did not wiject. - Viter contimuing the conversation a short time, Messes. Perrien and Sergeant left us, and I after transacting some offeial business also departed. The President spoke with some feching and in a very proper manner of the mol, that came the preceling night on his porch to insult him.

(1) Vidneway the is". Which was the usual tay for the meeting of the calmet, I went to the President's, and Messers. Berrien and sergeant were with him. Ife dis not by either word or manner invite me to join then so I retired into an adjoining room where I was soon joined by Messers. Mebster and Bell. We remained some time, and Mr. Wimer saying he had business retired and requested the servant to say to the President that he would come at his summons-after some time he was sent for and returned-but the door of the audience room Was still closed and we waited more than an hour before it was opened and we Wre in the meantime joined by Mr. Badger. At length the Presilent made his appearance-said he had been conversing with gentlemen who profesed to come informally as a committee of the Whigs of the two llouses to get his riews on the subject of the Bank-that he had doubts of the propriety of conferring with them and that he had stated those doulsts to them-said that he had his constitutional atriners about him with whom and with whom only he thonght he ought to crinsult and that having conferred with them his opinions could be male known to gentlemen on the part of the wo houses so far as it was proper to communicate it. Haring so said he began by asking us whether his views in that respect were correct. Mr. Webster replied that they were the same expressel hy Mr. Madison on some occasion (what I lo not remember) when he was consulted in like mamer. His explanation lrew from me the remark that the two cases probably differed in this-that appeared to have been a commitlee of one or both of the Ilumecs proper: this an informal mofficial deptrtation of political friculs who came to comsult with the l'resilent informally, to ascertain his opinions that they might if comsistent with their own vicus of the pullic cruml, conform to thems. But cren in that case I saw no improfriety, on the contrary much prutence in the l'resident's proposed course. of combulting with lis (abinet before he committed himself, even in-

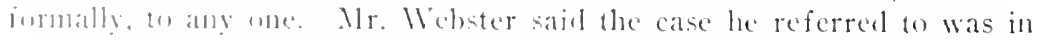

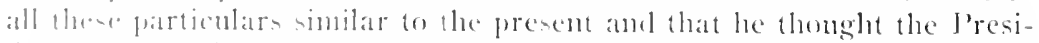

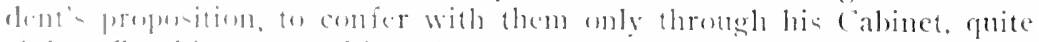

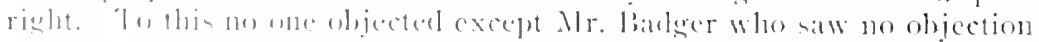

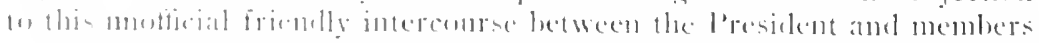

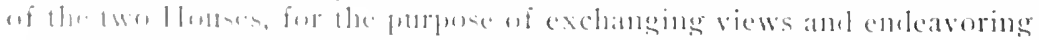

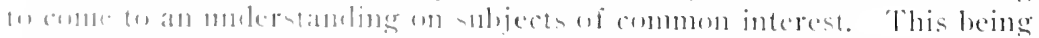

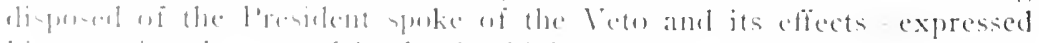

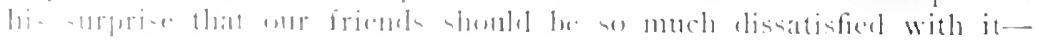


averred he believel it would be the salvation of the party if the Whigs in Congress would take it in a becoming spirit-spoke of the delay in taking the question mpon it in the Senate and expressed anxiety as to the tone and temper which the lebate wonlel assme there.

Badger-Mr. I'resident, I am hapjy to find on inquiry that the best temper in the world grevails generally in the two llouses on this sulject. 1 believe they are perfectly reaty to take up Mr. Ewing's bill and pass it withont alteration except in some mimportant particulars.

President-Talk not to me of Mr. Ewing's lill-it contains that olions feature of local discounts which I have repmliated in my message.

Eaing-1 have no doubt, sir, that the House, having ascertained your views, will pass a bill in conformity to them provited they can be satisfied that it will answer the purposes of the Creasury and relicve the colmetry.

Prosident-Cannot my (abinet see that this is brought about. You must stand by me in this emergency. Cammot you see that such a bill passes Congress as I can sign withont inconsistency?

Eaing-1 think a bill which will meet your views may be introduced into the Honse of Rep. and pass that body. Of the Senate I am not so certain. If such a bill coull pass both bodies speedily and receive your sanction, it would immediately restore harmony here and confidence throughont the nation.

Prosident-I care nothing about the Scnate-let the Bill pass the Honse with the understanding that it meets my approbation and the Senate may reject it on their own responsibility if they think best. But what do you understand to be my opinions? State them, so that there may be no misunderstanding.

Ewing-I understand you are of opinion that Congress may charter a Bank in the District of Columbia giving it its location here.

President-A nod of assent.

Eaing-That they may authorize such Bank to establish offices of Discomt and Deposit in any of the States with the assent of the States in which they are so established.

President (sharply)-Don't name Discomnts to me-they have been the source of the most abominable corruptions-and they are wholly unnecessary to cuable the Bank to discharge its duties to the country and the Govermment.

Eaing-I am proposing nothing, but simply endeavoring to recapitulate what I have heretofore understood to be your opinions as to the powers which Congress may constitutionally confer on a Bank. I now mnderstand your opinion to be, that they may not confer the power of local discomint even with the assent of the States.

President-(An expression of assent).

Eaving-And I tunderstand you to be of opinion that Congress may anthorize such Bank to estabjish agencies in the sereril states with power to receive, disburse or transmit the public monies and to deal in Bills of Exchange withont the assent of the States.

The President-les if they be foreign bills or bills drawn in one State and payable in another. That is all the power that is necessary for transmitting the public funds and regulating exchanges and the currency.

II b ster-I would like such a bill, with power to deal in Exchanges alone. without anthority derived from the States, much better than if it 
combincel the power of loseonnt with the assent of the states, and the jum er to deal in exchanges without such assent. I do not think it

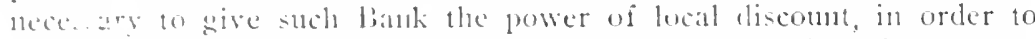

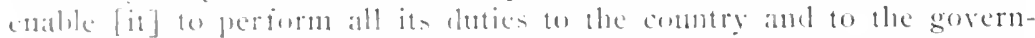

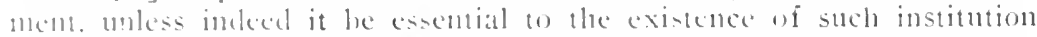
ambl then it is liable to the ohjection of athateling one implicel power to andelle which once almited might he carried to a dangerous extent. Snd there is an incongrotity in performing any of the necessary functions of the seneral fovernment by the sepatrate assent of individual stathes. If that which the L. S. whles to to he necesary in the discharge of its comstimtiomal duties. it has alrealy the assent of all the Siates wanted in and by the Constitution: if not neessary-there is no right to do it with such assent. That these particular powers are neces: inr -cents to me very clear, for the purpose of safe keeping and transmiting the pullic monies, for the restoration of a soumel currency, regulation of exchanges and especially of commeree between the states-and I helicve it will furnish sufficicnt inducements to capitalists to take the steck.

The l'resident expressed his acquiescence in the views of Mr. Melster-desired that we would see that the Bill should assume that form, and tepecially urged us to take care that it was placed in the hancls of some one in the Jumse who was his friend. Ewing enquired of himb whether Mr. Sergeant would be agrecable to him. He replied in the affirnative-wished us in communicating on the subject not to commut him personally, as having agreed to this project; for he was apprehensive it would be mate the subject of comparison to his prejudice - Hut adrised us to say that from the Veto Nessage and from all that we knew of his opinions we inferred that this wonld be acceptable. He then spolie of the name, which he wished should be so changed that it would not be called a IBank. To this there were some objections, but his wishes were funally acpuiesced in. Ile and Mr. Webster then convereet about the particular worling of the 16 " fundamental article and arreerl as to the form of expression which should introbluce the grant of power.

11. then repuested Messrs. Webster and Fwing to attend to getting it before the House and directed them to prepare for him as soon as prateticale an exposition in writing of their opinions upon it. Mr. bedl satd to Webter and Ewing-" Fentlemen you have no time to lose-if you do nut atfent to this today another bill less acceptable may be cort ip and reporterl." We were about retiring when the Presilent called Mr. Wistor batk. He remained a few mintes and then joined us. Mesers. Winter and lining then eomenlted as to the means of carrsing out the wishes of the l'resilent and it was agreed that Mr.

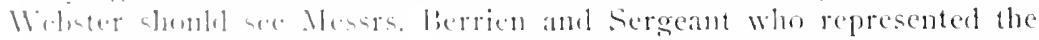
two Ilomes in this matter ant pussese them of the platn atereed on and

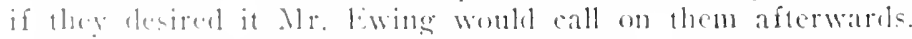

In a thert tine afterwatels I receiver a note from Mr. Mebster stating that Meness. Derrien and Seregent wished to see me at Mr.

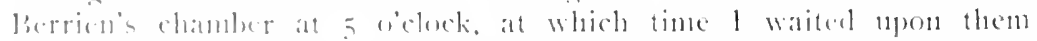
l'hey stated to nue that they hath combersed with the President that

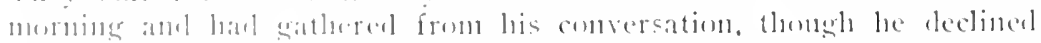

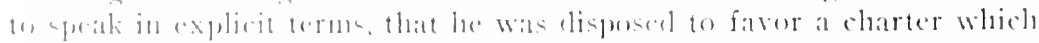

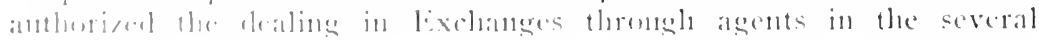

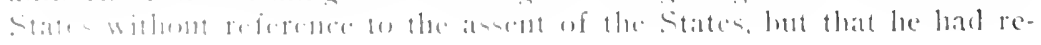


ferred them to his Cabinet after he should have consulted them. They also informed me that Mr. Webster had sugesested the particular frame and referted them to ne for my concurrence. Ifter full comversation they agreed to present the project, before onr political friends, and if asreed to by them in both branches it was to be intrufluced inte the Itouse. It is proper here to note that the Presiclent expressed great sensitiveness lest he shomld be commitled by anything that he or we should say to a project which would not be accopterl hy comeress and which would be contraster with that which he law rejecterl. And once in the course of the conversation he said le was bewildered-the had no time to collect his thoughts; why could not this thing be pustponed to the next session?

The Bill proposed could not he brought into the IIouse mutil that in the Sinate with the Presilent's objections was risposed of. This was done on the Ig" and Mr. Clay in the discussion made one of his most powerful and happy efforts-extorting expressions of rapturous applause from his most bitter encmies in that body, and thrilling his friends with delight. I was not present and consequently lost this noble intellectual treat, for it is wholly vain for Mr. Clay or any one else to attempt to transfer to paper any just presentment of his lofty and impassioned eloquence. But the President though treated with respect was sorely wounded, particularly by the popular impression which was anything but favorable to him. There was, it is said, in Mr. Clay's manner, an evident restraint and suppression of strong feeling while he spoke directly of the President, his position, his duty to the country, to those who placed him in power, and of his wide and unaccomtable departure from all those duties ${ }^{2}$ and his forgetfulness of all those obligations-but when Mr. Rives ${ }^{3}$ came out in the defence of the President and brought himself within the lion's bound, he sprang upon him with unrestrained and ummitigated impetuosity and poured forth upon him the whole torrent of his feclings in the most high toned and powerful invective. I had a report of the speech from MIr. Badger, himself an orator, who dwelt upon it with enthusiastic admiration.

I was taken ill on the night of the 19 " and did not get about mint Saturday, the 2 ist.

* Monday, the $23 \mathrm{~d}$, I called upon the President to transact some business and after conversing with him a few minutes Mir. Granger entered. The President soon introduced the subject of the Bank and his Veto and spoke with much feeling of the violence with which he was attacked and denounced by the Whigs and declared that he looked upon many of them as his very worst enemies. I told him it was what I had all along feared, if no means conld be devised by which the Veto could be avoided-that in truth the excitement was not so general or the expression of disapprobation as strong as I had apprehended and endeavored to show him would take place. Mr. Granger said there was much to be considered on botl siles, for, said he, "Sir, in every town and village, at the places where you and Genl. Harrison were insulted and denounced last fall, white the Whigs were supporting and defending you-flags are now hung out by your then enemies with Tyler and

"Word obscure, but seems to be "duties".

${ }^{3}$ Senator William C. Rives of Virginia.

* In the original this paragraph follows the fourth paragraph below. But a clean copy exists, made at some time for Mr. Ewing. in which the order is as herein given. 
the Veto inserted on them in large characters-they have their triumphal processions, burn tar barrels, fire cannon and rejoice while the irients who elevated gon either retire in silent sorrow or break out in expresions of disappointment or anger." To this the President replied little and we soon parterl.

On Saturlay the zist the l'resilent, the Secretary of Mar and myself went to the Arsenal to see smo experiments with improved rockets. In the course of conversation there he threw out very strong intinations that he would probally veto the liil which had lately been introlneed if it slould come to him.

Mombay the zid I sent him my argument upon the Bill as it then stool-having in the meantime received a printed copy of the Bill. Mr. IVehster's hat heen sent wp a short time before. The 25 th we had Cabinet Conncil-the l'resident seemed gloony and depressed-intimated in strong, terms that he woull not sign the bill and earnestly refuested us to get it postponed-said in reply to an expression of loubt on wr part that we hal got it np casily, we might postpone it as easily if we chose to do it. The seemed earnest and exigent that this shoulit be donle.

(In the 26" I conversed with him again in the presence of Granger. lle still carmestly solicited postponement, not as he said because of the political but of the personal difficulties which immediate action upon it wrolld insolve.

I meeting of the members of the Cabinet was called at Mr. Mebster's on the crening of the 27 " to take this matter into consideration. When after much consultation and a full interchange of opinions it was agreed wo endeavor to postpone, if we found it could be done by the sencral assent of the Whigs of the two Ilouses of Congress.

Sept. I. I short time before the Cabinet meeting tolay I called on Mr. Webster and fomed him in enversation with Mr. Rives, who suggested that Mr. Chay harl given notice in the evening that the Bank Pill wombl the taken up this morning, and funlly disposed of today. To thi he harl astien the consent of the opposition, who readily agreed to it. Mr. Rives having left us I asked Mr. Nebster if he had seen Mr. Evan" to infue him to holel a conversation with Mr. lierrien and if posilne set him to postpone the bill mutil after the passage of the revenue hill as I had renuested him last evening. lhe said he had not. I returneel to nuy office and sent my son to Mr. Fians, and then went to the l'rexillent's to Council.

I met Mr. harlger at the dowr and we went in together. Pell and Giranger were both there-the conversation first turned upon some inclifferent matters-pertaining to the War Department. The President then rextminerland sent to the Senate some nominations from the State I) phatument and tolel me that he hatl sent up all mine except the lialtimore. Appratisers that they objected to bis friend lester and he

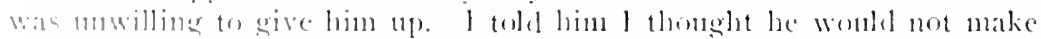
a enoul oflice lint that the names l had sent him were chosen with great

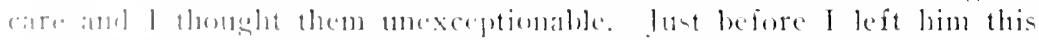
suldere was atsin alverted to and he said he nutse do something for

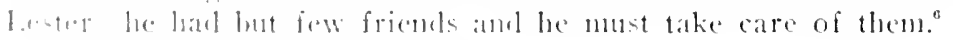

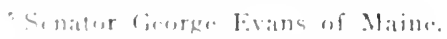

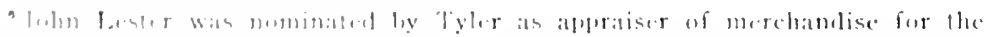

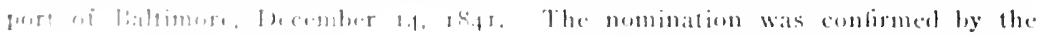


Messrs. Webster and Crittenden came in. A report on the Fortifications was produced and rean by Mr. liell. It was in reply to a resolution of the Senate passerl in March last calling for information at the commencement of the (then) next session. It was generally murlerstood that the next session meant the next regular session and Mr. Badger said that on consultation it ball beens so atgreed in Cabinet. 1 was not present at such agreement or do not remember it, but think the construction right nuless the contrary appear in the resolution. The report of $\mathrm{Mr}$. Fell was oljected to by all the other members of the (abinet, becanse it recognized a probable necessity of hereafter extending our fortifications very greatly-it was thought that he ought to have confined himself to the present wants of the conntry-namely, fortifications of the first class which can be completed at an expense of nine millions.

The Committee of the Sienate called and presented several enrolled bills for the Presirlent's signature-he signed all except the bill for the distribution of the procecds of the public I ands-this he rearl to usmade comments on some parts of it-talked jocosely about a l'ctoasked our opinion of the clanse oljected to, which was that which gives 500,000 acres each to the new States for the purpose of internat improvements. I placed that clause npon this ground. The U. S. is exempt from taxation by the States while a great proprietor of lands within the State-all other land holders are taxed for their improvements which greatly enhance the value of the land. The $\mathrm{C}$. S. as a proprietor ought to contribute to that by which it so much profits and this is the mode in which alone it can be done. Having conversed some time on the subject he askerl the Atty. General for an opinion on the point.

A few minutes were spent on the mole of paying onr Ministers abroad and a question raised as to the value of the pound sterling, on which I agreed to report.

Todd, the new Minister to Russia, called and much was said to him in ont presence of the importance of the mission. the precarions state of our relations with England and the necessity of having the aid of Russia in any contest with that power. His (the President's) manner during the session was courteons and kind-not perfectly frank though evidently striving to appear so. I thought the objections to the Land Bill a mere show of reason for keeping it awhile in band that he might approve it or not as political copediency should dictate.

On returning to the Department my son reported that he saw Mr. Evans who had used every effort to postpone the bill, but withont success. That Mr. Clay insisted on taking it 11 - - said he was not rearly to go on with the Revenue Bill-and that it was minerstood that the revenue bill should be laid on the table and the Bank bill taken up and risposed of, and he called upon the opposition to say if this were not the case-they vouched that it was-a rote was taken-all the Locos but one voted for taking up-I? Whigs against it, and it was taken up and consirlered-many of the Whigs were mucl incensed at Mr. Clay's contrse.

The events of the day cansed me much reflection. On the one hand Mr. Clay was evidently hurrying matters to a catastrophe, intending to hasten the new Bank bill upon Mr. Tyler; force him to approve or

i Colonel Charles S. Todd of Kentucly, under whom Motley served as secretary of legation. 
Veto- in the latter event compel the Cabinet to resign-lrive Tyler into the fonceratic party- lenounce the Administration and malie himself as the lead of the Nhig party an opposition candidate for the l'resileney. lihs opinion was formed from a consideration of previous matlers connected with the doings of the day. Shomld these things tatie place and slould I resign and mite in such a movement, I wonkd lue smbjected to the imputation of having been a false comsellor to the l'resilent-ncar his person-admitled to his secret comeils, and at the same lime conniving with and abetting his most hitter adversary in his attempt to overthow him, and when the movement came in which he was involved inextricably with having abandoned him to his fate and openly joined the enemy:

()n the other hand if I should remain in the Cabinet after another Veto through the seene of excitement and in the midst of the denumeiation conseguent upon it, I would be charged with having abandoned my well known principles and broken up old associations for the love of oflice. It also secmed certain that some members of the Cabinet would resign. Those who should remain, must be associated with persons whom we did not esteem and whose political principles were aclverse to ours. The situation of such of us would be the most mpleasant that could be conceived. We would be made the constant object of attack by the papers on both sides in politics, and probably be at last compelled to resign or be displaced, with injured characters, and minds soured and discontented. What was to be done?

I conversed very freely with Mr. Bell on the evening of this day and compared opinions and impressions with him. He concurred with me entirely as to the difficulty of our situation but declared that he would not resign for a Veto on the Bank Bill-nor in the event of resignation for other cause or removal, would he mite in or consent to the nomination of Mr. Clay, at this time. On the supposition of a V'eto on the lamel Bill his opinion as well as mine was in favor of Resignationnot beamse we differed from the Presilent in two important measures but because in both he had been false to us-and because we believed the Veto upon those two bills made the evidence complete, that he betrayer the party by which we were all brought into power and sold limself to the arlversary.

In the evening late iranger called on me. We compared notes and concurred in opinion. I Ie said Mr. Clay had lost many friends by the hot haste with which he pressed the Pank Bill forward-spoke of the sreat imprulence of putting the Pank hill before the revenue bill, if he really desired that the Lanel Bill should he approved.

of in the whole I lecame satisfied that Mr. Clay was impatient, and mulaply in his then present position. He had heen the modisputer leater wi the Whig party for many years while they were in a minority and he combl not well endure now they were in power, that his supermecy shombl be questioned or the power over the party divided.

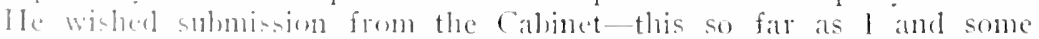
uflere were conecrued was impossible. I wouhl not even ennsult with

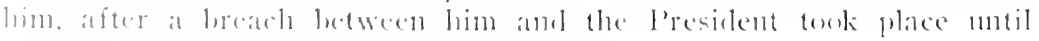

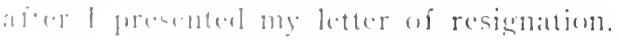

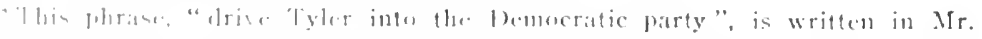

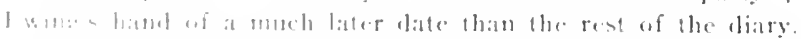

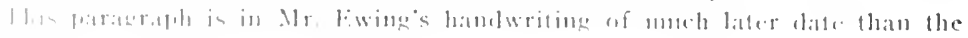


Sept. 2d. Nothing special occurret. The l'resilent, the ( abinet and the chairmen of the connentee of foreign Retations of the Senate and Ilouse dined with Mr. IV chster. In the conrse of the corening the President said to we that he had Mr. Seliten"s" views as wo the chrofice of depositories of the problic nuoney which he wisled to sulmuit to ne. That he was very anxions to hold the Treasmor responsible on his bond. He said he mulerstood I had setected the liank of commere in New Jork, which I told him was the case. Ile sail he wanted to suggest some stipulations and I said I would send him the contract. In the evening we hat a large party at Mr. Bell's where the I'resilent attenclect.

I had in the conrse of the day a long contersation with ficorge Summers, who said the miversal opinion was that the cabinet shomld hold their places nutil actually removed by the President. 'That the comtry considered us as holding by a higher tenure than merely his appointment, and that a resignation would be consinlererl as an abandomment of the post which Gent. Harrison and the Nation hat assigned us, and if the President chose to add this last crowning sin to his alreatly great transgression that it should be his act not ours, he should be held responsible for it.

I also conversed during the day with Goode and Stokely members from Ohio and with Alfred Kelly all of whom united strongly in the same opinion. ${ }^{12}$ I put the case to them of a Veto on the Bank bill in progress in the house-it was, they said, on the supposition of that Veto they had nrged their opinion. I then put the case of a Veto on the Land Bill which would show a clear and fixed purpose to abandon the Whigs and their principles and throw himself into the arms of the opposition. On that they hesitated but inclined to the opinion that we should still hold onr places and let him do the last crowning act of dismissal which they said wonld be esteened by the people a sacrilegious desecration of the memory of the beloved Harrison.

The speech of Mr. Clay in the Senate, this day as reported by Mr. Fletcher Webster $^{13}$ was in his happiest manner, and was much spoken of (see the papers).

It was told me in the evening that Mr. Rives had called in the conrse of the day upon the President and proposed an amendment to the Bank Bill, providing that if any state should expressly dissent, that the corporation thereafter should not be suffered to deal in Exchange within its limits except so far as the wants of the Treasury required -which amendment he. Mr. Rives, was willing to support and that being inserted to vote for the Pill. The President declined having anything to do with the modification and preferred that the Bill should be sent to him in its then present form.

My letter to Luther Barker ${ }^{14}$ published in the Madisonian this morning was read and commented upon by Mr. Buchannan in the Senate.

1" William Selden, treasurer of the United States.

${ }^{11}$ reorge W. Summers, representative from Virginia.

${ }^{12}$ Patrick G. Goode and Samuel Stokely were representatives from Ohio, Alfred Kelly a man prominent in the management of the state's finances and father of the Olicio Canal.

${ }^{13}$ Son of the Secretary of State, and at this time his private secretary

${ }^{\text {t4 }}$ Luther D. Barker had been a fellow-student of Mr. Ewing's at Olio Unirersity. 
It was smken of al limner by Mr. Mebster in terms of commendation. The publication of that letter did not, in the opinion of onr friends at all strengthen the position of the President.

\section{Ertract from "Madisonian"-Sipt. 2d, IS fI.}

"The position taken hy the Iresinlent, that the people did not decide in the election of 1 s.fo in favor of any particular scheme of finance, most of unr realers will ahmit has been fully sustained.

" We hare received, however, a communication signed by five of onr subcriber at l'iketown, Ohio, taking a very different view. They ctate that the issue was presented in (hio, and decided in favor of a liank ly an innense majority. They are of course hostile to the Veto, and think that mothing will he sommd or settled without a Bank. IVe hope they will he content with this simple notice to their communication. Nhengh they have on their sisle the aid of the Senator of Kentucky, yet they and he must atmit that there is at least room for an honest liffercuce of opinion on the subject. We happen to have before us lirectly in point, the testimony of a well known, and influential witness from their uwn state. Whose opinion we know they will respect, denouncing the attenpt hring the election to make the question of a bank the isstle hetween the parties, to be impudent and absurd. We refer to the following letter from the present distinguished head of the Treasury Department."

My I I (1) Sir:

L.ANCASTER, July I\& 40

(1) 1my return from (olumbus this evening I received your letter informing me that, in a speech at Philadelphia, I had said the true question between the parties was a Bank of the United States, and that you from a knowledge of me had contradicted the assertion. In this you were of course perfectly safe. I made no such statement but the very contrary. I arowed that the true question was and is the restriction of Executive power. That its encroachments, open and covert, were of the most alarming nature, and if not resisted must end in the subversion of all that is valued in the Republican principles of our Government, and that a gorgon's monarchy in effect if not in name must rise on its ruine I said that our opponents were attempting to make the fuestion oi bunk the istue between the parties. I spoke of the impudence and absurdity of the attempt. That a Bank was not and never hatl been consilered $h$ us as anything more than a matter of convenicnee a uneful article of furniture of our noble edifice. That our oppuncuts were gravely raising and debating the guestion whether this article of furniture was convenient or necessary. Whether we should have a tuble or a setter standing in our halls, while its sappers and miner wre at work tmmbling its walls and columns abont our ears. This witl anplification and illustrations, is the substance of what I said enelines that particular oliject.

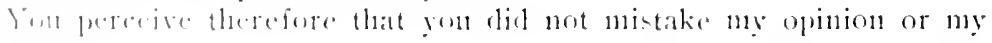
lit11:3lits...

$$
\text { Vont sincere liriend }
$$

T. EWING 
Sept. 3d. Today I sent the l'resilent a cony of my letter of contract with the lianks acompronying it with a note in which I sail I woukl be happy to receive and consider any suggestions which he might choose to offer. I diel not call to see him, lut understoul from Mr. licil that he was disposed to talk on business nerely, but was jucose and cheerful. Several of my friculs called today to offer me their commsel, which was miformly the same as that noter yesterdity.

I called to see Mr. Welsster and had a longe compersation with him. He expressed great anxicty alomt the comblitin of thing and scencel to inticipate a rlissolution of the cabinet. Ite satid he coubl not sleep well of nights, for thinking of it-said if he were rich he would mot mind it personally, but that he felt great mowillingues at his age w return to the liar. We agrees that the situation at the luead of at department here was envible, if the I'resident harl intellect and wat in harmony with his cabinet and all supporterl by a gond majority in the two houses. Spoke of a resignation in a certain event but desired to ascertain whether the President had been bargaining with the aclversary.

Sept. fth. Called on the resirlent this morning and found Messrs. Bell and Granger with him. Mr. Melster came in soon after.

The conversation turned on the Land Bill which was lying on the table, before the President. He declared that it was his wish to approve it, but he objected to one clatuse as containing a recognition of the right of Congress to appropriate land and therefore money to internal inprovements which right he denied. He drew up a declaration of his opinion on that subject, which on consultation underwent some modifications-he said he would have it copied in a fair hand and place one copy in the hands of each nember of his Cabinet. He asked our opinion as to the time of sending up the Land Bill. The liank Pill was passed and would probably be Vetoed; should he retain the Land Pill and send up both together or send the Land Bill immediately? The latter course was advised and resolved upon, as the more frank and generous-he having known of the passage of the Bank Bill before he approved the other.

The committee on Enrolled Bills came in and brought the Bank Bill to the President and withdrew. He wished to converse with us on the subject in the most perfect confidence-he should probably be compelled to Veto the Bill and he thought of accompanying the Veto with a solemn declaration that he would not be a candidate for the Presidency another term-said he had no ambition except to preserve a pure unsullied reputation, protect the constitution and promote the interests of the comntry and he thought such declaration would place his motives fairly before the people and disarm those who were assailing him. The members of the Cabinet present did not concur in these views and they were very readily surrentered by the President. Ile was generally it is true tenacions of his opinions but on this point he showed great deference to the views of his Constitutional alvisers. In the course of the conversation he said that he had indited a sentence intended for insertion in his inaugural, expressly declaring that lie would not be a candidate for reelection: which he witheld lest its effect should be to turn the batteries of Mr. Clay and his friends on Mr. Mebster.

He evidently felt anxious and mhappy. He observed that coming to the Presidency as he did, without being prominent in the canvass, he 
rallicel no friculs around him and had no party. That a singular spectacle was now presented-heretofore if a member of the Administration party abandoned the President he was instantly assailed and certainly prostrated, hut now whocver ventured to support the President was as cortainly rumed. He talkel of his meditated Veto message-said he should criticise the bill with much severity. Mr. Nebster thought it injurmlent and not entirely consistent with official dignity to do so-that such a paper ought to be calm. elevated and full of dignity. The hope was expresed ly some of us that he might yet approve the bill and we parted.

I walked to the Department with Mr. Webster who said we must prepare the public through the press for the event and wished me to call and see him in the morning.

Sipt. 5". After reflecting very fully on what occurred at the President's yesterday, I made up my mind that we ought not yet to give up the question or attempt to bring the public mind to an acquiescence in it. I called on Mr. Mebster and gave him my views fully which were-

That the President bad given him a fine opening for a free and confidential conversation at which he might tell him in the fulness of gratitude and in the sincerity of friendship the whole truth as to his present position-to show him the certain ruin of private reputation and political power consequent upon the contemplated Veto and perhaps induce him to avoid the gulf into which he was about to plunge. Well knowing the motives likely to operate on the mind of the President I suggested to Mr. Webster this course of conversation-

Ist. To express his grateful feelings to the President for the friendly consileration of himself (Mr. M.) which had governed his (the Presilent's) action in framing his inaugural.

21. To speak of his own relations with Mr. Clay, and how and why there was not and could not be cordial amity between them.

31. To speak of the other members of the Cabinet. Their willingness to support the l'resident against any and all assailants if he would] hut give them gromel to stand mpon. That for myself. I was well impresed with the fact that Mr. Clay exacted great sacrifices of his friculle and was willing to sacrifice nothing to them. That 1 was the iriend of Mr. (lay as he the l'resident) had been his friend, but that I Would unt fail to suntan the delministration to which I belonged against any attack which Mr. Clay might think fit to make upon it. That I womld he rery far trom sacrificing my oren cortain present, to his contingent future. That at to Mr. Bell, he was lese strongly hound to Mr. (lay than was uppesed; that he folt that he had sacrificed enough to Mr. Clay"s ambition aml that he would be willing to go in cordially with the l'resilent if this means were furmished of sustainims himself.

Mewrs. liarlger and firanger not being friends of Mr. Clay could be the sulpect of wn jeatoung and the presence of $\mathrm{Mr}$. Critenden as a member of the (abinet woblel serve to avert attacks, in the mischief of which, if mate he must share.

fth. That he bumbl refier to the ungugestions of The President yester-

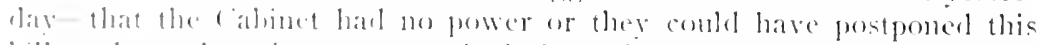
bill, and aly that circumbtances latel placed it ont of their power to exert their influence in thin hut that their true strength was tested in getting

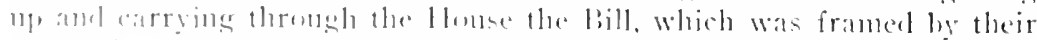

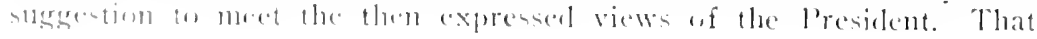


cessor ad interim-catused my letter of resignation to he recorded and dispatched nyy messenger with it to the l'resilent. Junt as I was leaving the department Mr. Mebster's messenger cimle with a rerplest that I would see him inmediately. I called and fomml him at his table with my letter of resignation lying hefore hin-he tosk it up as if weighing in his hand and asked ne if I recognized it and anled, "it is a harsh

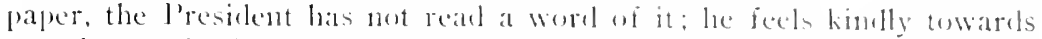
you, has authorized ane to kell you so, and that ats you are determined to resign, if gon part in friendship, he will give your elosec of foreign Missions-think better of it and withdraw this letter." I tohl him it was impossible-that my people nust know why I left the renpunsible posi-

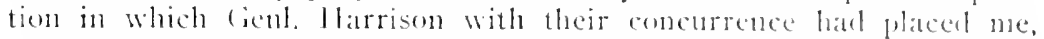
that the reasons were set forth in that letter and I ham mate up my mind to abide by it. He told me he hat determined to remain for the present-that there was one important fact stated which I could have got from no one but him and as it might disturb his relations with the Iresident he wished me to change the sentence and return the paper to him. I went asain to the Preasury Department, mate the change-hat the record corrected and returned the letter. ${ }^{16}$

It was published in the Intelligencer Monday morning and cauned much sensation. ${ }^{17}$ Mr. Webster suffered much by remaining in the (abinet, with his new associates. It was a mistake from the effects of which he never recovered. My friends who advised me not to resign after the publication of my letter approved what 1 hat done.

Pelow is a copy taken from the Intelligeneer. The record in the Department seems to have been destroyed.

${ }^{13}$ In Tyler's Letters and Times of the Tylers, II. 122, note, is a story of the receipt of the letter of resignation by the President and of Webster's taking it. given in a letter of $\mathrm{IS}_{3}$ by Joln Tyler, jr., the president's son and private secretary.

${ }^{17}$ Reprinted in Niles' Register. LXI. 33-34, and partly in Benton, Thir!y Y*ars' I 'ie'i, II. $3+3-3+5$. 
he malit not to forget the circumstances under which that bill was got tij) and the sitmation in which we were placed with regard to it. That it lid wut at first meet the views of the members of either house-the cumntry had not spoken tpon it and the House was not willing to pass it mutil they had the assurance of the Senate that it would pass through that buty. (On full consultation this assurance was obtained and by our interession and throush our influence-hence after the passage of the linl in the llouse a few members of the Senate could not consistently with acrol faith, unite with the Locos and defeat the Bill nor could we in good faith ask then to do it; and it was not strange that the two honies should be nuwilling, after passing the Bill through one Branch and finding it not only acceptable, but carmestly desired by the country, to abanton it without being able to render a reason to their constituents for such act. Hence it was not a case to test the influence of his Callinct.

5th. That he should fully and carefully examine the situation of the J'rendent, as to the Bill. Iis committal in the Veto Message-in his inamptral-in his message to the two houses at the opening of the Session and his conversation to members of Congress, declaring his concurrence in sttels a bill.

oth. That he should muleceive lim as to the supposed powerful effect of the public monies in regulating the currency.

$\mathrm{I}_{11}$ all this Mr. Mebster concurred and wrote a note to the President saying that he would see him tomorrow morning.

The Whic papers from all the West and $S$. W. today Were filled with the most bitter dentunciations against the P'resident on account of the first Veto. The signature of the Iand Bill drew down upon him heary animallersions from some of the Locos in the Senate yesterday (coniersation between Vise and Beilly Peyton yesterday). And the rumor was rife that the President through Judge Upsher and Alex. Hamilton offered the situation of Attorney-General to MeMabon of Baltimore who rejected it with disclain and indignation as a proposed act of treachery to the Mhig party.

- Ifter onr repeated conversations with the President and modification to meet his views and remove his objections $\mathrm{Mr}$. Mebster and my- di felt quite safe in asuring Mr. Berrien and Mr. Sergeant that the bitl as we hat nomlificel it, if passed hy the two llonses would receive his snetion. It was on passed withent the change of a word, and when. I acertined that he hat Vetoed it. I parted with a determination never (1) mect him again as a member of his Cabinct. Indeed I conbl not feel that nue reputation as a man of truth and candor was safe, while I attempted th feprecent him. I went to my bepartment and atrised him

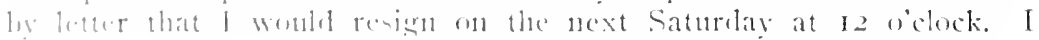
urote nuy letter of renignation - sent him a hank appointment for a suc-

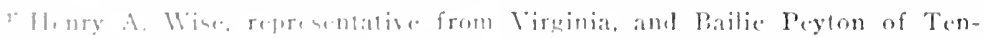

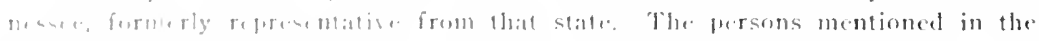

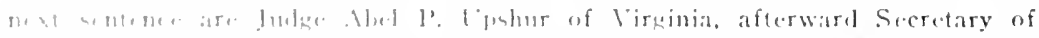

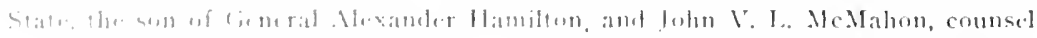

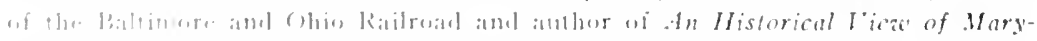

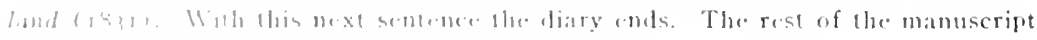
is in Mr lawing in landwriting of much litler ditle. 
<smiles>CCCCC</smiles> 
LIBRARY OF CONGRESS

II UI H HUH

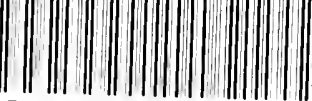

$0011895 \quad 5791$ 